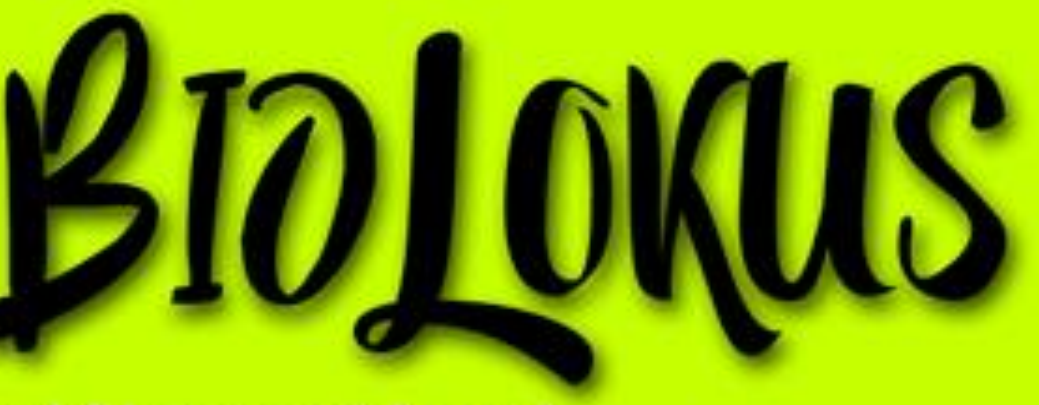

Journal of Biological Education and Research

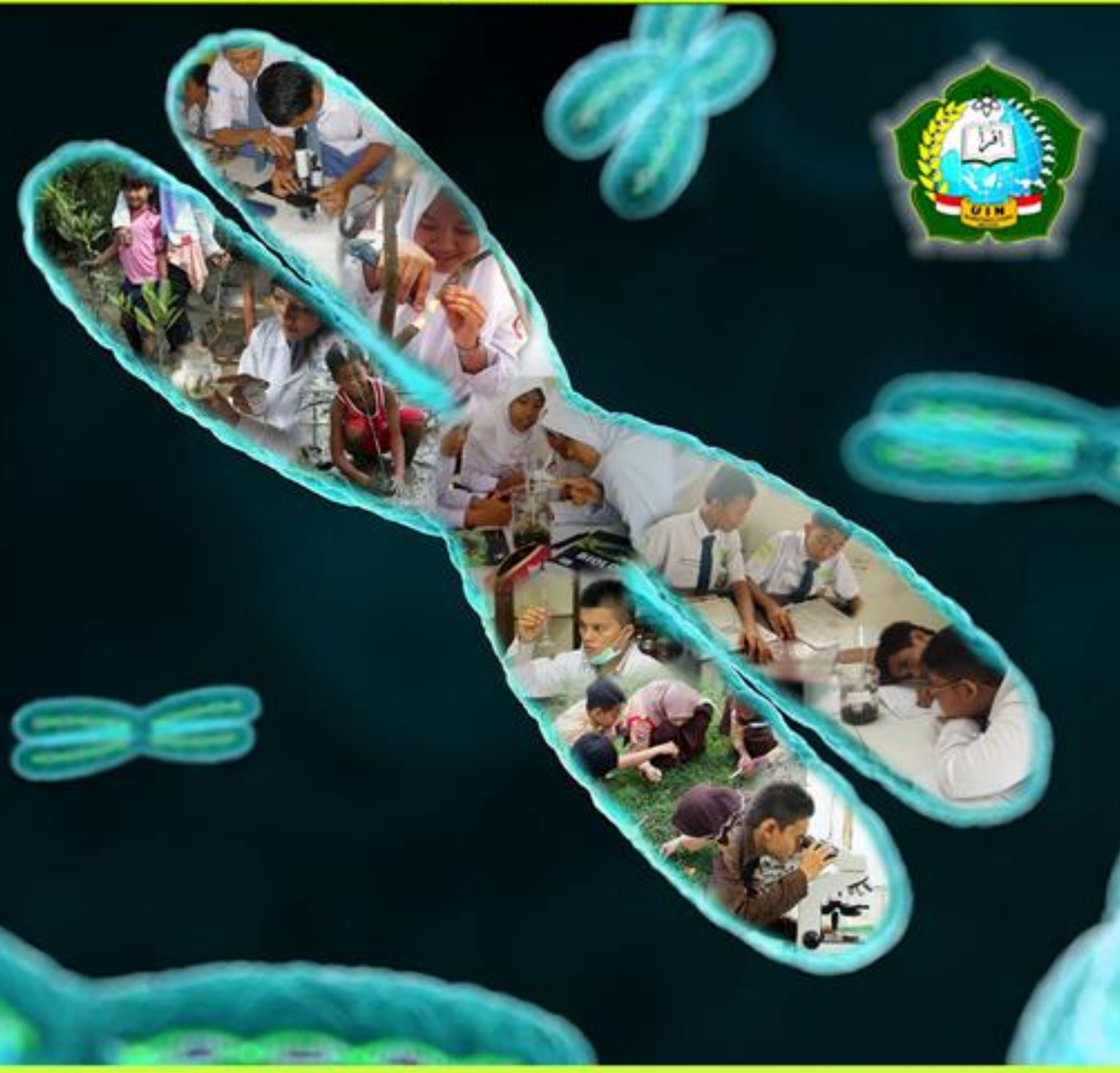

PRODI TADRIS BIOLOGI FAKULTAS ILMU TARBIYYA DAN KEGURUAN UNIVERSTTAS ISLAM NEGERI SUMATERA UTARA 


\section{DAFTAR ISI TERBITAN}

$180-185$

186-194

195-201

202-209

210-216

$222-227$

228-233
PENGARUH MODEL PEMBELAJARAN MIND MAPPING TERHADAP HASIL BELAJAR SISWA PADA MATERI RESPIRASI DI KELAS XI SMA NEGERI 2 BILAH HULU

Rahmi Nazliah, Risma Delima Harahap, dan Elysa Rohayani Hasibuan

PENGEMBANGAN MODUL BERORIENTASI PREDICT, OBSERVE, EXPLAIN (POE) PADA MATERI VIRUS TERHADAP KOGNITIF SISWA

Fitri Agustina Lubis dan Ayunda Sabrina Sormin

ANALISIS RENCANA PELAKSANAAN PEMBELAJARAN (RPP) BIOLOGI KURIKULUM 2013 KELAS X SEMESTER 1 TAHUN AJARAN 2016/2017 DI MAS ISLAMIYAH GUNTING SAGA KUALUH SELATAN KABUPATEN LABUHANBATU UTARA

Risma Delima Harahap dan Rahmi Nazliah EFEKTIVITAS PENERAPAN MODEL PEMBELAJARAN TGT (TEAMS GAMES TOURNAMENTS) TERHADAP PRESTASI BELAJAR BIOLOGI PADA SISWA KELAS XII MIA-5 MAN 3 MEDAN

Satriawati MENINGKATKAN KOMPETENSI PROFESIONAL GURU DALAM
MENYUSUN RENCANA PELAKSANAAN PEMBELAJARAN KURIKULUM
2013 MELALUI WORKSHOP DI SMP SWASTA AMANDA
Henny Ramdaniar

MENINGKATKAN HASIL BELAJAR SISWA PADA PELAJARAN ILMU PENGETAHUAN ALAM DI KELAS VII-2 MELALUI PENDEKATAN PEMBELAJARAN CARA BELAJAR SISWA AKTIF DI SMP NEGERI 29 MEDAN Sauli Farida Siregar MENINGKATKAN KEMAMPUAN KEPALA SEKOLAH DALAM MENGELOLA SEKOLAH MELALUI WORKSHOP TOTAL QUALITY MANAGEMENT DAN SUPERVISI MANAJERIAL DI SMP BINAAN

Arizona

PENINGKATAN KEMAMPUAN BERPIKIR KRITIS SISWA MELALUI MODEL PEMBELAJARAN KOOPERATIF THINK PAIR SHARE

DI KELAS X SMA NEGERI 4 PADANGSIDIMPUAN

Heni Mulyani Pohan dan Ade Isma Hasibuan 


\title{
PENGARUH MODEL PEMBELAJARAN MIND MAPPING TERHADAP HASIL BELAJAR SISWA PADA MATERI RESPIRASI DI KELAS XI SMA NEGERI 2 BILAH HULU
}

\author{
Rahmi Nazliah'1 (rahmi.nazliah@gmail.com) \\ Risma Delima Harahap1 (rismadelimaharahap@gmail.com) \\ Elysa Rohayani Hasibuan'1 (elysa.hasby@gmail.com) \\ ${ }^{1}$ Program Studi Pendidikan Biologi \\ Sekolah Tinggi Keguruan dan Ilmu Pendidikan (STKIP) Labuhanbatu
}

\begin{abstract}
ABSTRAK
Penelitian ini bertujuan untuk mengetahui pengaruh hasil belajar pada materi respirasi yang diajarkan dengan menggunakan model pembelajaran Mind Mapping di kelas XI SMA Negeri 2 Bilah Hulu. Jenis penelitian quasi eksperimen dengan sampel Total Sampling. Kelas XI1 sebagai kelas eksperimen dengan model pembelajaran Mind Mapping sedangkan kelas XI2 sebagai kelas kontrol dengan model pembelajaran konvensional. Instrumen dalam penelitian ini menggunakan tes hasil belajar bentuk pilihan ganda. Teknik analisis data menggunakan uji $t$ berpasangan pada taraf signifikansi $\alpha=0,05$. Hasil Uji Hipotesis data Post-test model pembelajaran Mind Mapping dan model konvesional diperoleh $t_{\text {hitung }}=17,947$ dan daftar $t_{\text {tabel }}=1,686$. Sehingga $t_{\text {hitung }} \geq t_{\text {tabel }}(17,947 \geq 1,686)$. Sehingga Ha diterima dan HO ditolak. Simpulan penelitian ini terdapat pengaruh hasil belajar siswa dengan menggunakan model pembelajaran Mind Mapping pada materi respirasi. Dengan demikian Model Pembelajaran Mind Mapping lebih baik digunakan pada materi respirasi dibandingan dengan Model Pembelajaran Konvesional.
\end{abstract}

Kata Kunci : Mind Mapping, Konvesional, Hasil Belajar, Respirasi.

\section{ABSTRACT}

This study aims to determine The Influence of Mind Mapping Learning Model on the Results of Student Learning Outcomes on Respiration Materials in Grade XI SMA Negeri 2 Bilah Hulu Year 2017/2018. This type of research uses quasi experimental research with total sampling sample. Class XI1 as experiment class is taught by usingMind Mapping Learning model and class XI2 as control class is taught by conventional learning model (cerama). The research instrumen used the multiple choice form learning test results. Data analysis technique using paired t test at significance level $\alpha=0,05$. Result of Hypothesis Test of Post-test data of Mind Mapping learning model and conventional model obtained thitung $=17,947$ and list of $t_{\text {tabel }}=1,686$. So $t_{\text {hitung }} \geq t_{\text {tabel }}(17,947 \geq 1,686)$. So Ha is accepted and HO is rejected. Then there is influence of student learning outcomes by using Mind Mappinglearning model on respiration material. Thus the Mind Mapping learning model is better used in the respiration material compared with the conventional learning model.

Keywords : Mind Mapping, Convensional, Learning Outcomes, Respiration

\section{PENDAHULUAN}

Dalam proses belajar mengajar sering sekali siswa mengalami kendala, seperti kurang memahami materi, malas, mengantuk, bosan, dan sebagainya. Siswa memiliki kemampuan yang berbeda-beda dalam menerima materi yang disampaikan guru, ada siswa yang mudah memahami materi yang disampaikan oleh guru dan ada pula siswa yang tidak mudah memahami materi yang di sampaikan oleh guru, sehingga pengaplikasian konsep biologi yang diharapkan dalam kehidupan sehari-hari tidak terealisasikan dengan baik.
Berdasarkan dari observasi yang dilakukan di SMA Negeri 2 Bilah Hulu, Pembelajaran masih terjadi dalam satu arah pembelajaran masih berpusat guru (student centre) bahwa masalah tersebut berdampak pada hasil belajar siswa yang rendah. Hal tersebut dapat dilihat dari nilai hasil belajar siswa siswa yang masih berada di bawah standart nilai kreteria ketuntasan minimun (KKM) yaitu 79, sementara nilai hasil belajar yang diperoleh siswa dibawah KKM. Berdasarkan sumber yang diperoleh bahwa pencapaian nilai siswa pada pelajaran biologi belum memenuhi KKM. 
Selain itu model pembelajaran yang digunakan guru di sekolah tersebut masih belum sesuai dengan proses kegiatan belajar mengajar dan siswa kurang aktif selama kegiatan belajar mengajar. Model pembelajaran yang dapat membantu meningkatkan hasil belajar siswa salah satunya adalah dengan menggunakan model yang bervariasi, siswa akan dapat meningkatkan hasil belajarnya. Model yang dipilih dalam penelitian ini adalah model pembelajaran Mind Mapping. Model pembelajaran Mind Mapping atau peta pikiran, adalah salah satu cara mencatat materi pelajaran yang memudahkan siswa belajar. Mind Mapping bisa juga dikategorikan sebagai teknik mencatat kreatif, dalam penjelasan yang lebih sederhana, peta pikiran (Mind Mapping) adalah suatu teknik mencatat yang mengembangkan gaya belajar visual. Peta pikiran memadukan dan mengembangkan potensi kerja otak yang terdapat di dalam diri seseorang. Mind Mapping bisa disebut sebuah peta rute yang hebat bagi ingatan, memungkinkan kita menyusun fakta dan pikiran sedemikian rupa sehingga cara kerja alami otak dilibatkan sejak awal.

Mengadakan variasi model pembelajaran merupakan hal yang sangat perlu dilakukan oleh guru, agar pembelajaran yang dibawakan oleh guru lebih menarik dan membuat siswa semangat untuk mengikuti pembelajaran yang akan dibawakan oleh guru.

\section{METODE dan WAKTU PENELITIAN}

Penelitian ini akan dilaksanakan di SMA Negeri 2 Bilah Hulu. Waktu penelitian dilaksanakan pada bulan April sampai dengan bulan Juni 2018. Populasi dalam penelitian ini adalah seluruh kelas XI IPA SMA Negeri 2 Bilah Hulu yang berjumlah 74 siswa yang terdiri dari 2 kelas yaitu kelas XI1 berjumlah 38 siswa dan XI2 berjumlah 36 siswa. Teknik pengampilan sampling yang dilakukan adalah purvosive sampling, dengan desain penelitian sebagai berikut:

Tabel 1. Desain Penelitian.

\begin{tabular}{cccc}
\hline Kelompok & Pretest & Perlakuan & Posttest \\
\hline Eksperimen & $\mathrm{Y}_{1}$ & $\mathrm{X} 1$ & $\mathrm{Y}_{2}$ \\
Kontrol & $\mathrm{Y}_{1}$ & $\mathrm{X} 2$ & $\mathrm{Y}_{2}$ \\
\hline
\end{tabular}

Keterangan:

Y1 : Tes awal atau Pretest

Y2 : Tes akhir atau Possttest

X1 : Pemberian perlakuan (Model Pembelajaran Mind Mapping)

X2 : Pemberian perlakuan (Model Ceramah)
Adapun prosedur dan tahap-tahap penelitian ini adalah sebagai berikut; (1) Tahap persiapan; (2) Tahap pelaksanaan; (3) Tahap pengumpulan data. Dalam teknik pengumpulan data, terlebih dahulu ditentukan sumber data, dan instrumen yang digunakan. Adapun langkahlangkah teknik validasi dalam penelitian sebagai berikut: (1) Uji Validitas Tes; (2) Reliabilitas Tes; (3) Taraf Kesukaran Tes; (3) Daya Pembeda Tes; (4) Teknik Analisis Data dengan menggunakan program SPSS 22,0 for windows.

\section{HASIL DAN PEMBAHASAN}

\section{Hasil Belajar Pre-Test Kelas Eksperimen dan Kelas Kontrol}

Hasil uji coba data Pre-Test Kelas Eksperimen diperoleh jumlah nilai $=1725$, nilai rata-rata $=$ 45,394 ; standar deviasi $=8,882$; varian $=78,894$. Nilai yang diperoleh siswa tertinggi 65 dan terendah 30, sedangkan Kelas Kontrol diperoleh jumlah nilai $=1580$, nilai rata-rata $=43,888$; standar deviasi $=9,419$; varian $=88,730$. Adapun diagram batang yang dapat menggambarkan teknik analisis data hasil belajar siswa Pre-Test pada kelas eksperiman dan kelas kontrol adalah sebagai berikut:

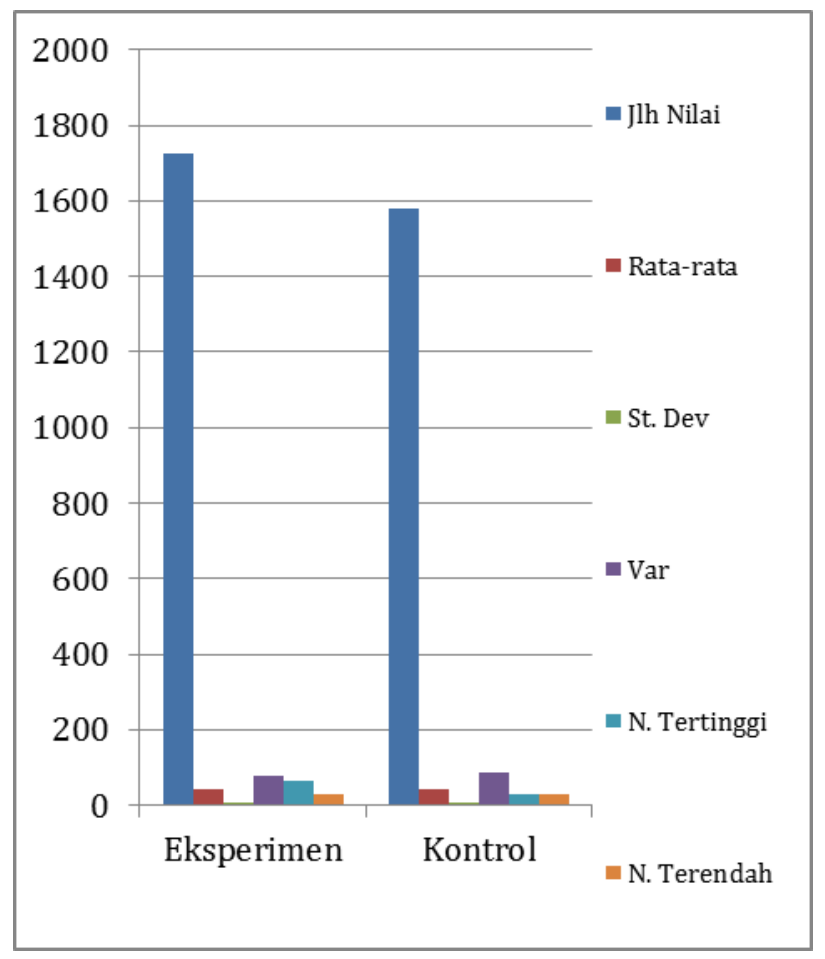

Gambar 1. Diagram Batang data hasil belajar siswa Pre-Test Kelas Eksperimen dan Pre-Test Kelas Kontrol. 
Hasil Belajar Post-test Kelas Eksperimen dan Kelas Kontrol

Hasil uji coba data post-test kelas eksperimen diperoleh jumlah nilai $=2825$, nilai rata-rata =74,342; standar deviasi = 8,068; varian $=65,096$. Nilai tertinggi 90 dan nilai terendah 60, sedangkan kelas control diperoleh jumlah nilai $=2505$, nilai rata-rata $=69,583$; standar deviasi $=10,648$; varian $=113,392$. Adapun diagram batang yang dapat menggambarkan teknik analisis data hasil belajar siswa post-test pada kelas eksperiman dan kelas kontrol adalah sebagai berikut :

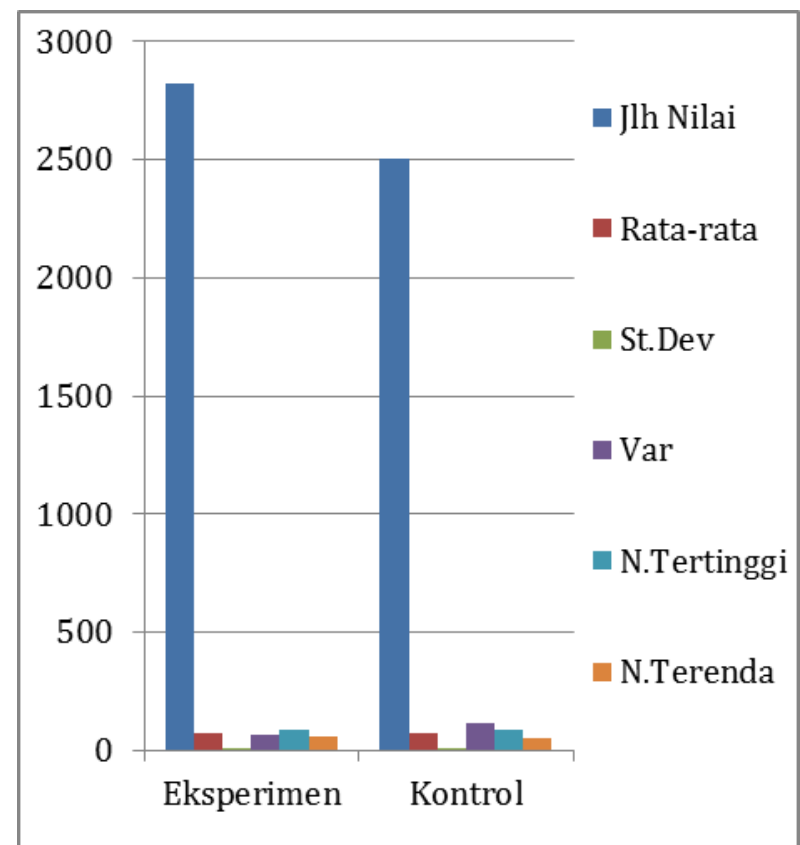

Gambar 2. Diagram Batang data hasil belajar siswa Post-test kelas eksperimen dan kelas Kontrol.

Uji Normalitas Pre-Test Kelas Eksperimen Dan Kelas Kontrol

Uji normalitas data pre-test pada kelas Eksperimen (XI1) diperoleh nilai signifikan sebesar $(0,156>0,05)$ dan data pre-test pada Kelas Kontrol (XI2) diperoleh nilai signifikan sebesar $(0,127>0,05)$. Hal ini dapat kita lihat pada tabel di bawah ini.

Tabel 2. Hasil Uji Normalitas Pre-Test Eksperimen dan Kontrol.

\begin{tabular}{|c|c|c|c|c|c|c|c|}
\hline & \multirow{2}{*}{$\begin{array}{l}\mathrm{Ke} \\
\text { las }\end{array}$} & \multicolumn{3}{|c|}{$\begin{array}{c}\text { Kolmogorov- } \\
\text { Smirnov }\end{array}$} & \multicolumn{3}{|c|}{ Shapiro-Wilk } \\
\hline & & $\begin{array}{l}\text { Stati } \\
\text { stic }\end{array}$ & df & Sig. & $\begin{array}{l}\text { Stati } \\
\text { s tic }\end{array}$ & $d f$ & Sig. \\
\hline \multirow{2}{*}{$\begin{array}{l}\text { Hasil } \\
\text { belajar }\end{array}$} & 1 & .123 & 38 & .156 & .941 & 38 & .044 \\
\hline & 2 & .127 & 38 & .127 & .955 & 38 & .131 \\
\hline
\end{tabular}

Adapun diagram batang yang dapat menggambarkan teknik analisis data hasil uji normalitas pre-test pada kelas eksperiman dan kelas Kontrol adalah sebagai berikut:

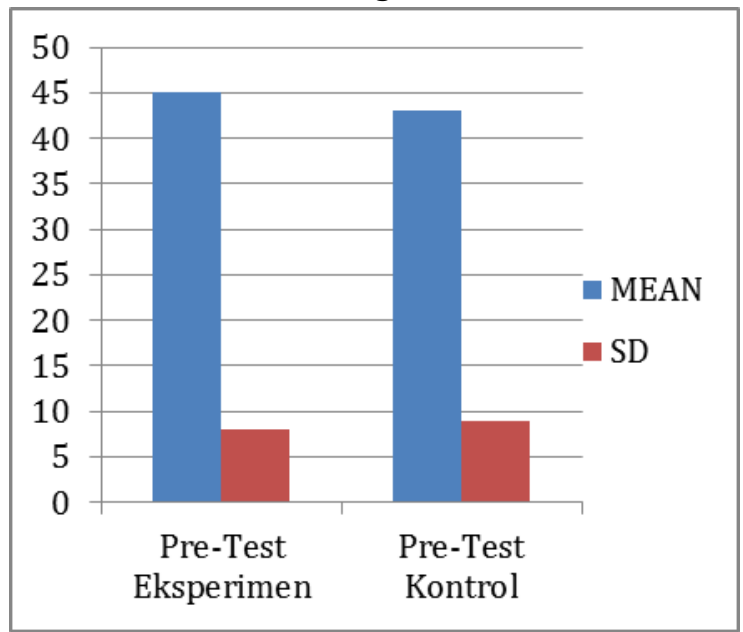

Gambar 3. Diagram Batang Hasil Uji Normalitas Pre-Test kelas eksperimen dan kelas kontrol.

\section{Uji Normalitas Post-Test Kelas Eksperimen Dan Kelas Kontrol}

Berdasarkan hasil perhitungan data Post-test di kelas Eksperimen (XI1) diperoleh nilai signifikan $(0,109>0,05)$ dan data Post-test pada Kelas Kontrol (XI2) diperoleh nilai signifikan $(0,199>0,05)$ hal ini dapat kita lihat pada tabel di bawah ini:

Tabel 3. Hasil Uji Normalitas Post-Test

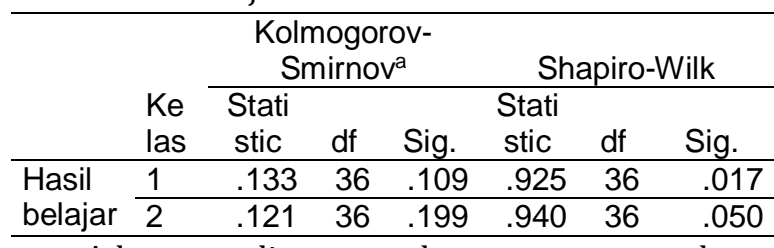

Adapun diagram batang yang dapat menggambarkan teknik analisis data hasil uji normalitas Post-test pada kelas eksperiman dan kelas kontrol adalah sebagai berikut:

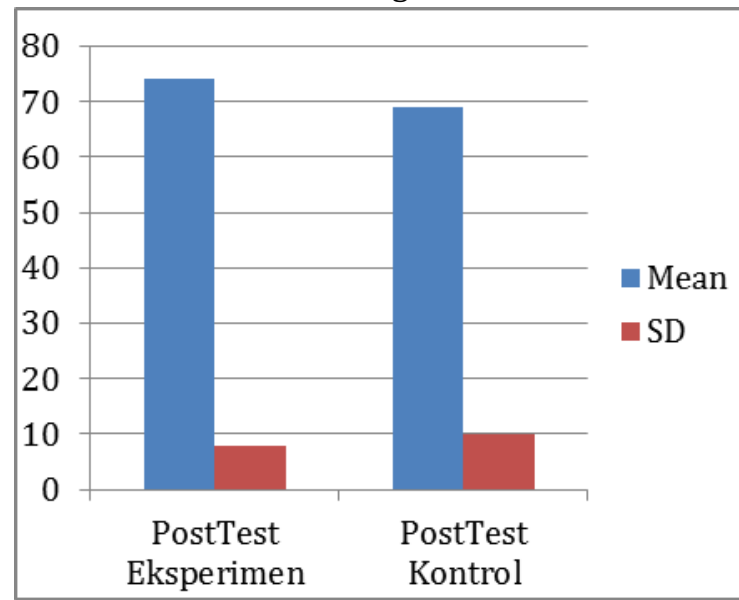

Gambar 4. Diagram Batang Hasil Uji Normalitas Post-test kelas eksperimen dan kelas kontrol. 


\section{Uji Homogenitas Pre-Test Kelas Eksperimen dan Kelas Kontrol}

Berdasarkan hasil perhitungan data PreTest pada kelas eksperimen dan kelas kontrol Uji Homogenitas diperoleh nilai signifikan $(0,481>$ $0,05)$ yang menunjukkan nilai signifikan dari Test Of Homogenity of Varience pada Pre-Test pada Eksperimen dan kelas Kontrol diperoleh nilai signifikan $(0,481>0,05)$, hal ini dapat kita lihat pada tabel di bawah ini:

Tabel 4. Hasil Uji Homogenitas Pre-Test.

\begin{tabular}{lrrrrr}
\hline & $\begin{array}{c}\text { Sum of } \\
\text { Squares }\end{array}$ & df & $\begin{array}{c}\text { Mean } \\
\text { Squ } \\
\text { are }\end{array}$ & F & Sig. \\
\hline $\begin{array}{l}\text { BetweenG } \\
\text { roups }\end{array}$ & 41.920 & 1 & 41.920 & .501 & .481 \\
\hline $\begin{array}{l}\text { Within } \\
\text { Groups }\end{array}$ & 6024.635 & 72 & 83.675 & & \\
\hline Total & 6066.554 & 73 & & & \\
\hline
\end{tabular}

Adapun diagram batang yang dapat menggambarkan teknik analisis data hasil uji homogenitas Pre-Test pada kelas eksperiman dan kelas kontrol adalah sebagai berikut:

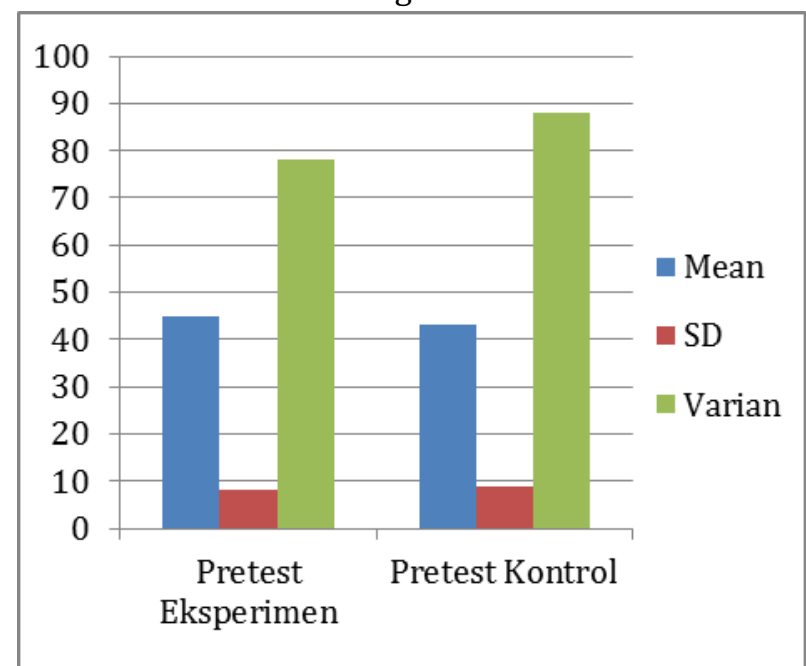

Gambar 5. Diagram Batang Hasil Uji Homogenitas Pre-Test kelas eksperimen dan kelas control.

\section{Uji Homogenitas Post-Test Kelas Eksperimen Dan Kelas Kontrol}

Perhitungan data Post-test pada kelas eksperimen dan kelas kontrol Uji Homogenitas diperoleh nilai signifikan $(0,330>0,05)$, yang menunjukkan nilai signifikan dari Test Of Homogeneity of Varience pada Pre-Test kelas eksperimen dan kelas Kontrol diperoleh nilai signifikan $(0,330>0.05)$, hal ini dapat kita lihat pada tabel di bawah ini :
Tabel 5. Hasil Uji Homogenitas Post Test

\begin{tabular}{lcrccc}
\hline & $\begin{array}{c}\text { Sum of } \\
\text { Squares }\end{array}$ & df & $\begin{array}{c}\text { Sean } \\
\text { Square }\end{array}$ & F & Sig. \\
\hline $\begin{array}{l}\text { Between } \\
\text { Groups }\end{array}$ & 418.643 & 1 & 418.643 & 4.726 & .330 \\
\hline $\begin{array}{l}\text { Within } \\
\text { Groups }\end{array}$ & 6377.303 & 72 & 88.574 & & \\
\hline Total & 6795.946 & 73 & & & \\
\hline
\end{tabular}

Adapun diagram batang yang dapat menggambarkan teknik analisis data hasil uji homogenitas Post-test pada kelas eksperimen dan kelas kontrol adalah sebagai berikut :

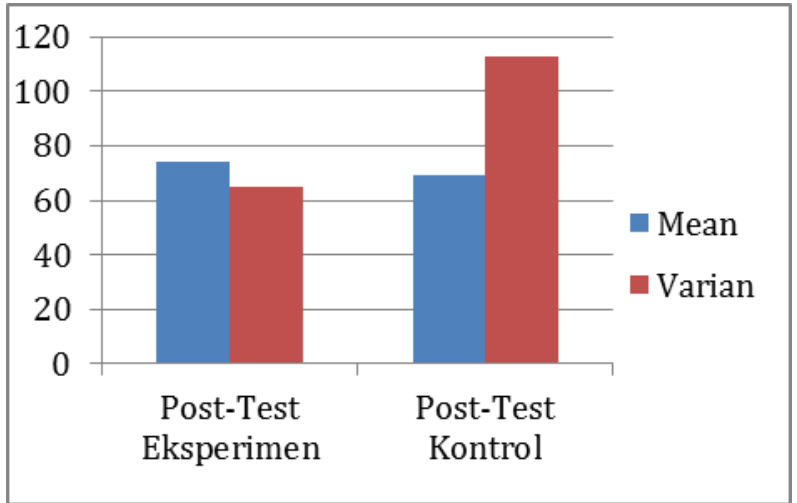

Gambar 6. Diagram Batang Hasil Uji Homogenitas Post-test kelas eksperimen dan kelas control.

\section{Pengujian Hipotesis}

Berdasarkan hasil perhitungan data Pre-Test uji hipotesis pada kelas eksperimen dan kelas kontrol diperoleh nilai signifikan $=0,554$ dengan taraf signifikan $\alpha=0,05$ dan $\mathrm{df}=38-2$ sehingga diperoleh daftar ttabel $=1,686$ aturan untuk menguji tolak $\mathrm{H0}$ adalah jika thitung $\geq$ ttabel atau nilai signifikan > 0,05 $(17,947<1,686)$. Dengan demikian $\mathrm{Ha}$ yang menyatakan bahwa ada pengaruh hasil belajar siswa dengan menggunakan model pembelajaran Mind Mapping pada materi respirasi diterima dan $\mathrm{H} 0$ ditolak.

\section{PEMBAHASAN}

Berdasarkan penelitian yang saya lakukan, model pembelajaran Mind Mapping sangat baik untuk diterapkan dalam pembelajaran Materi Respirasi di kelas XI SMA Negeri 2 Bilah Bulu karena memiliki pengaruh terhadap hasil belajar siswa dan model ini lebih baik jika dibandingkan dengan menggunakan model ceramah (konvesional) pada materi respirasi di kelas XI SMA Negeri 2 Bilah Hulu. Hal ini disesuaikan dengan rata-rata hasil belajar yang diperoleh. Pada kelas eksperimen menggunakan model 
pembelajaran Mind Mapping mempunyai nilai ratarata Pre-Test sebesar 45,39 dan Post-test sebesar 74,34. Dari sini kita lihat perubahan yang sangat baik dalam proses pembelajaran dan bisa menafsirkan bahwa model pembelajaran Mind Mapping memiliki pengaruh terhadap hasil belajar siswa, dan jika dibandingkan dengan kelas kontrol menggunakan model pembelajaran Konvesional memiliki nilai rata-rata Pos-Test yaitu 69,58. Hal ini menunjukkan bahwa kelas eksperimen yang diajarkan dengan model pembelajaran Mind Mapping lebih besar daripada kelas kontrol yang diajarkan dengan model pembelajaran konvesional. Mind Mapping merupakan model pembelajaran kooperatif yang mulai dikembangkan. Pada dasarnya pembelajaran ini dilaksanakan dengan kegiatan belajar siswa secara kelompok menggunakan Mind Mapp. Mind Mapping merupakan teknik mencatat yang menyenangkan karena melibatkan warna, gambar dan kata.

Penelitian ini juga linier dengan hasil penelitian Lubis, F.A (2018) bahwa diketahui ada perbedaan hasil belajar siswa melalui penerapan strategi pembelajaran inkuiri divariasikan media mind mapping dengan strategi pembelajaran inkuiri. Begitu juga dengan Satriawati (2019) dalam meningkatkan hasil belajar dan aktivitas siswa melalui Mind Mapping dengan kombinasi dengan Numbered Head Together dapat meningkatkan hasil belajar dan aktivitas belajar biologi siswa dari siklus I sampai siklus II. Mind mapping merupakan salah satu cara kreatif bagi siswa untuk menghasilkan gagasan, mencatat apa yang dipelajari, atau merencanakan tugas baru.

\section{SIMPULAN}

Berdasarkan hasil penelitian dan pembahasan, makadapat diperoleh simpulan yaitu Ada pengaruh model pembelajaran Mind Mapping terhadap hasil belajar siswa pada materi respirasi di kelas XI SMA Negeri 2. Pada taraf signifikan $a=$ 0,05 dengan thitung $\geq$ ttabel $(17,947 \geq 1,686)$. Maka Ha diterima dan $\mathrm{HO}$ ditolak.

Hasil belajar siswa pada kelas eksperimen yang diajarkan dengan model pembelajaran Mind Mapping pada materi respirasi dikelas XI SMA Negeri 2 Bilah Hulu pada nilai Post-test diperoleh nilai rata-rata sebesar 74,342 dengan standard deviasi 8,068.

\section{REFERENSI}

Adrian. (2004). Alat Ekresi Pada Manusia. Jakarta : Bumi Aksara.

Arikunto, S. (2012). Dasar-Dasar Evaluasi Pendidikan. Jakarta : Bumi Aksara.

Aunurrahman. (2009). Belajar dan Pembelajaran. Bandung : Alfabeta.

Buzan, Tony. (2005). Buku Pintar Mind Map. Jakarta: Gramedia.

Djamarah, Syaiful Bahri. (2011). Psikologi Belajar. Jakarta : Rineka Cipta.

Fadhilaturrahmi. (2017). PENERAPAN METODE MIND MAPPING UNTUK MENINGKATKAN HASIL BELAJAR MAHASISWA SEMESTER IIA PGSD MATAKULIAH PENDIDIKAN MATEMATIKA SD KELAS RENDAH. Journal Cendekia: Jurnal Pendidikan Matematika, 1(1).

Fealasofi, Rahma., Arnidha, Yunni., \& Istiani, Ana. (2015). METODE PEMBELAJARAN MIND MAPPING UNTUK MENINGKATKAN KEMAMPUAN KOMUNIKASI MATEMATIK SISWA DALAM PEMECAHAN MASALAH MATEMATIK. Jurnal e-DuMath, 1(2).

Hamalik, Oemar. (2011). Proses Belajar Mengajar. Jakarta : Bumi Aksara.

Isnaini, Muhammad., Aini, K. \& Anggraini, R. (2016). PENGARUH STRATEGI PEMBELAJARAN MIND MAPP TERHADAP PEMAHAMAN KONSEP PADA MATERI SISTEM EKSKRESI KELAS XI IPA SMA $\begin{array}{lll}\text { NEGERI } & 1 \text { PAMPANGAN }\end{array}$ Jurnal Bioilmi, 2 (2).

Kurniasih, Imas \& Sani, Berlin. (2015). Ragam Pengembangan Model Pembelajaran. Jakarta: Kata Pena.

Lubis, F. A. (2018). PENGARUH PENERAPAN STRATEGI PEMBELAJARAN INKUIRI DIVARIASIKAN DENGAN MEDIA MIND MAPPING TERHADAP MINAT BELAJAR SISWA. Jurnal Biolokus, 1(2), 93-100.

Pratiwi, D.A., Maryati, Sri., Srikini., Suharno., \& S. Bambang., (2012). Biologi Untuk SMA dan MA Kelas XI. Jakarta: Erlangga. 
Rusman. (2012). Model-Model Pembelajaran Mengembangkan Profesionalisme Guru. Jakarta: Rajagrafindo Persada.

Satriawati. (2019). UPAYA MENINGKATKAN HASIL BELAJAR DAN AKTIVITAS SISWA MELALUI IMPLEMENTASI MODEL PEMBELAJARAN MIND MAPPING DIKOMBINASIKAN DENGAN NUMBERED HEAD TOGETHER MATERI SISTEM EKSKRESI MANUSIA PADA KELAS XI MIA 1 MAN 3 MEDAN TAHUN PELAJARAN 2017/2018. Jurnal Biolokus. 2(1) , 128-134.

Widyasari, L.A., Sarwanto., \& Prayetno, B.A., (2013). PEMBELAJARAN BIOLOGI MENGGUNAKAN MODEL ACCELERATED MELALUI CONCEPT MAPPING DAN MAND MAPPING DITINJAU DARI KREATIVITAS DAN KEMAMPUAN VERBAL SISWA. Jurnal Inkuiri. Vol. 2, No. 3. 